BIOKEMISTRI 17(1):1-6 (June 2005)

Available online at $h t t p: / / w w w . b i o l i n e . o r g . b r / b k$.

Abstracted online at www.ajol.info/journals/biokem

Printed in Nigeria
An international journal published by the<smiles>[C]1=C2SC=CC=C12</smiles>

OVigerian \&ociety for E̊xperimental ß̊iology

\title{
Comparism of xanthine oxidase activities in cow and goat milks
}

\section{Evans C. EGWIM*, Mohammed A. VUNCHI and Patience O. EGWIM}

Department of Science Laboratory Technology, Federal Polytechnic, PMB 55, Bida, Niger State, Nigeria

Received 20 February 2004

MS/No BKM/2004/005, (c) 2005 Nigerian Society for Experimental Biology. All rights reserved.

\begin{abstract}
The activities of xanthine oxidase were studied in cow and goat milks. The optimum temperature and $\mathrm{pH}$ values were $10^{\circ} \mathrm{C}$ and 7.5 ; and $20^{\circ} \mathrm{C}$ and $7.2-7.4$ for cow and goat milk samples respectively. The substrate effect on xanthine oxidase from both milk samples followed the popular Michealis Menten's $\left(\mathrm{K}_{\mathrm{m}}\right)$ equation. The $\mathrm{K}_{\mathrm{m}}$ and $\mathrm{V}_{\max }$ were $0.86 \times 10^{-2} \mathrm{M}$ and $3.7 \mathrm{Msec}^{-1}$ and $4.36 \times 10^{-2} \mathrm{M}$ and $2.0 \mathrm{Msec}^{-1}$. The work concludes that xanthine oxidase from cow and goat milk differs both in their basic characteristics and in the kinetic activities.
\end{abstract}

Key words: xanthine oxidase. Milk, kinetic parameters

*Author to whom all correspondence should be addressed.

E-mail: evansegwim@yahoo.com, Tel: 08036832178 


\section{INTRODUCTION}

Xanthine oxidase is a highly versatile enzyme that is widely distributed among species ( from bacteria to man) and within the various tissues of mammals. It is a member of a group of enzymes known as molybdenum iron - sulfur flavin hydroxylases ${ }^{1}$. Xanthine oxidase catalyses the hydroxylation of purines, and in particular xanthine to uric acid. It is one of the major enzymes involved in the catabolism of purine nucleotides. It converts hypoxanthine to xanthine and xanthine to uric ${ }^{2}$ The uric acid product from xanthine oxidase catalysis contributes to the antioxidant capacity of the blood. The reduction of $\mathrm{O}_{2}$ and $\mathrm{H}_{2} \mathrm{O}_{2}$ in the xanthine oxidase catalysis has been proposed as a central mechanism of oxidase injury in some situations ${ }^{3,4}$

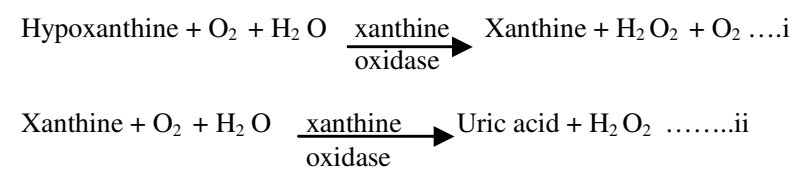

Xanthine Oxidase has been implicated in several physiological and pathological cases. It has been shown to reduce Cyt b5 and p -450 in mammalian hepatic microsomes under anaerobic condition ${ }^{5}$.It has also been shown to have antiturmor activity ${ }^{6}$

Allopurinol, a competitive inhibitor of xanthine oxidase, has been used to treat gout patients ${ }^{7}$. Industrially, Xanthine oxidase been used to monitor fish freshness in fish industries ${ }^{8}$. Xanthine oxidase has also been immobilized to form a broke instrument for industrial and diagnostic uses ${ }^{9}$.

It is on this background of the several applications of xanthine oxidase that the present study is designed to compare the xanthine oxidase activities from different milk samples.

\section{MATERIALS AND METHOD}

Cow and goat milks used for the present study were obtained from Bida, Niger state, Nigeria. Chemicals used were all reagent grades and products of $\mathrm{BDH}$ and sigma chemical companies, Poole St Louis USA.

\section{Xanthine oxidase Assay}

Enzyme assay was carried out according to the method described by Beckman, et al, ${ }^{10}$ which involves monitoring the rate of appearance of uric acid at $320 \mathrm{~nm}$ according to equations $\mathrm{i}$ and ii

\section{Calculation}

Enzyme activity in different milk samples was calculated

$$
\text { Unit } / \mathrm{ml}=\frac{\Delta \mathrm{A} / \min \mathrm{X} 100 \times 3 \mathrm{ml} \times \mathrm{D}}{5 \min \times 1.22 \times 10^{4} \times 0.1 \mathrm{ml}}
$$

Where

Enzyme unit $/ \mathrm{ml}=$ activity (which is $\mathrm{mg}$ uric acid / minute at optimal conditions )

$\Delta A / \min =$ Change in absorbance per minute

$\mathrm{D}=$ Dilution factor of milk sample (10) i.e 1:10 dilution.

$1.22 \times 10^{4}=$ Molar absorbance of uric acid.

$3 \mathrm{ml}=$ Total volume of assay solution

$0.1 \mathrm{ml}=\quad$ Volume of milk sample.

Determination of concentration, $\mathrm{pH}$ and temperature profiles

Enzyme assay was repeated using different substrate concentrations $(0.002$ to $0.120 \mathrm{mg} / \mathrm{ml})$; different $\mathrm{pH}(6.8,7.0,7.2,7.4,7.6$, 7.8 and 8.0) and different temperature $\left(5^{\circ} \mathrm{C}\right.$, $10^{\circ} \mathrm{C}, 15^{\circ} \mathrm{C}, 20^{\circ} \mathrm{C}, 25^{\circ} \mathrm{C}, 30^{\circ} \mathrm{C}, 35^{\circ} \mathrm{C}, 40^{\circ} \mathrm{C}, 45^{\circ} \mathrm{C}$, and $50{ }^{\circ} \mathrm{C}$ ). This was used to determine optimum $\mathrm{pH}$ and temperature of xanthine oxidase activity from the different milk samples.

Lineweaver-Burk plot $\frac{1}{v}$ vs $\frac{1}{[S]}$ was used to determine the kinetic parameters $\left(\mathrm{K}_{\mathrm{m}} \& \mathrm{~V}_{\max }\right)$ of xanthine oxidase from different milk samples.

\section{RESULT AND DISCUSSION}

Temperature activity profile of xanthine oxidase from cow and goat milk is shown in Fig. 1. The optimum temperatures for xanthine oxidase from cow and goat milks are $10^{\circ} \mathrm{c}$ and $20^{\circ} \mathrm{C}$ respectively. The present observation suggests that xanthine oxidase from different origin may 


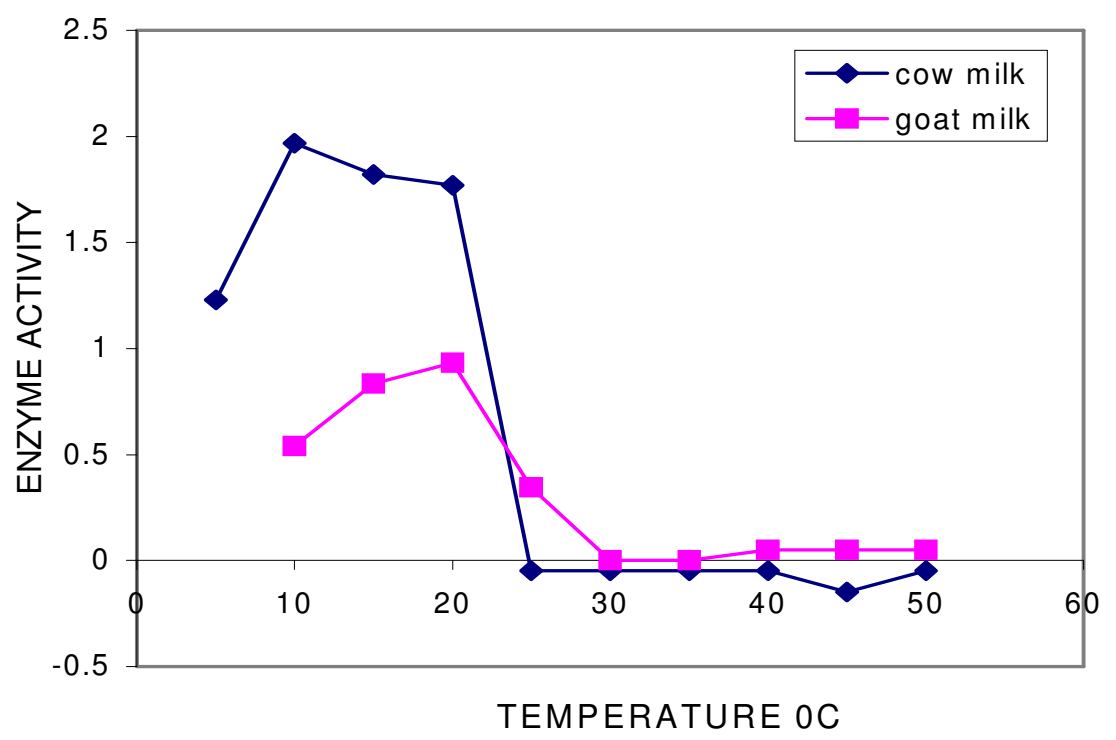

Fig. 1 Temperature activity profile of xanthine oxidase from cow and goat milks

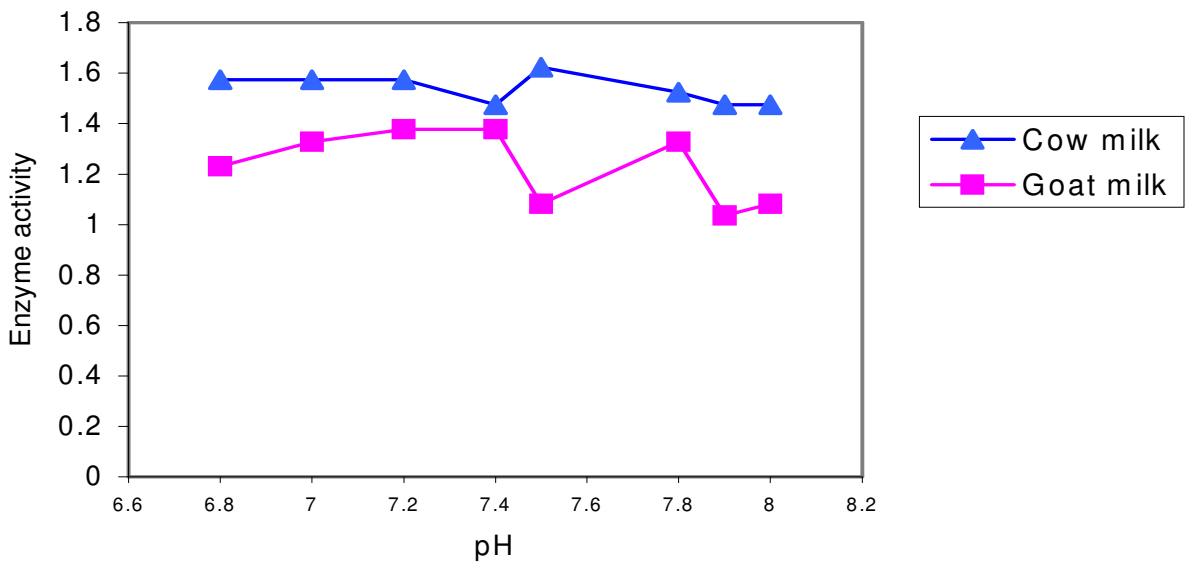

Fig. $2 \mathrm{pH}$-activity profile of xanthine oxidase from cow and goat milks

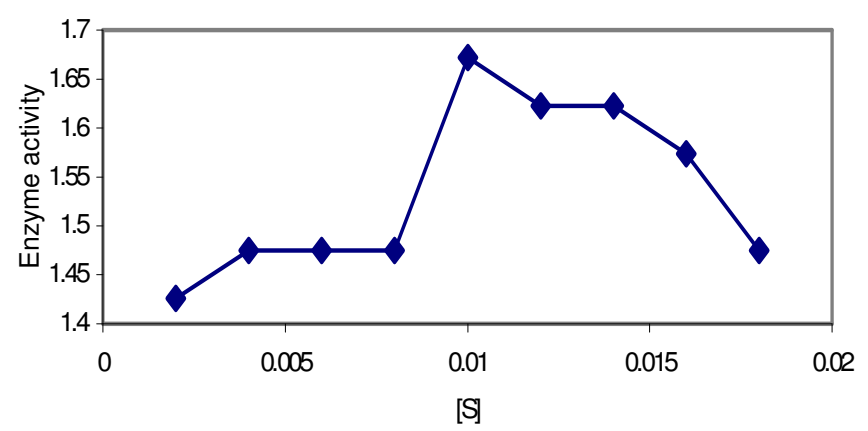

Fig. 3Substrate-Activity profile of Xanthine oxidase fromøowmilk 


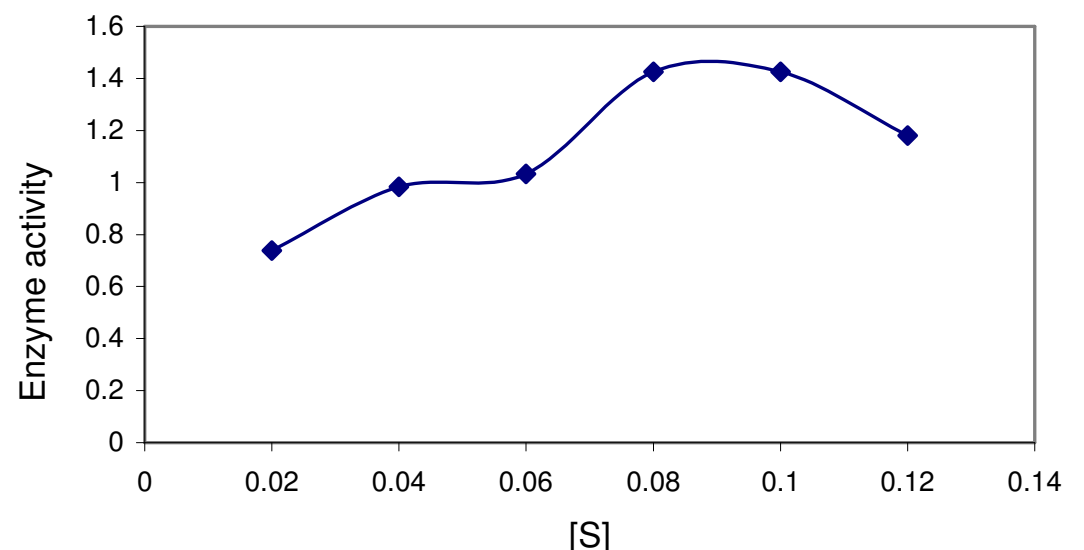

Fig.4 Substrate-Activity Profile of Xanthine oxidase from Goat milk

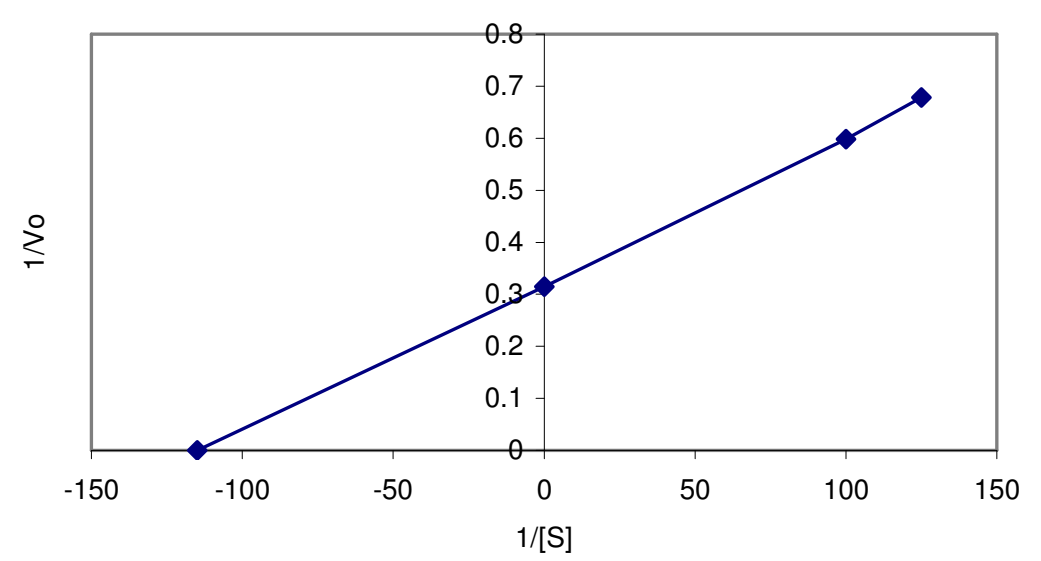

Fig. 5 Lineweaver-Burk plot of Xanthine oxidase for Cow milk

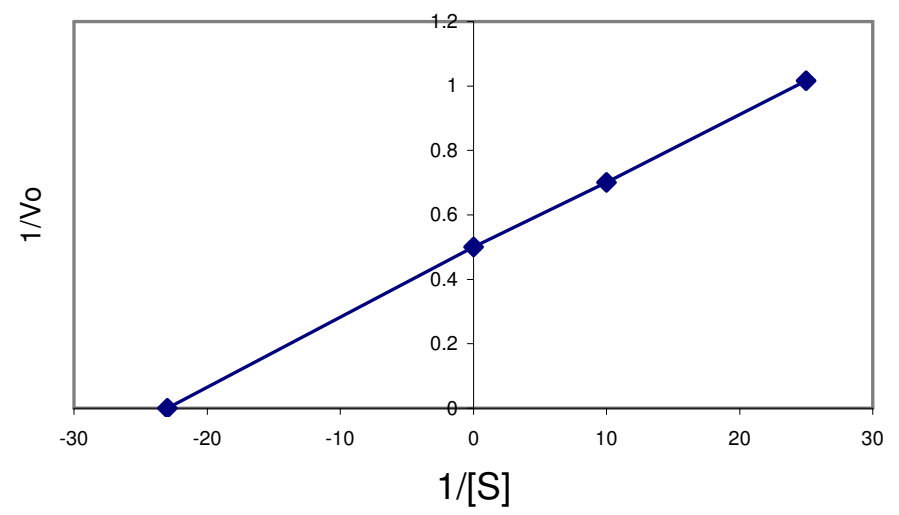

Fig. 6 Lineweaver-Burk plot of Xanthine oxidase from Goat milk 
differ in their basic characteristics. However, the value for optimum temperature observed for the xanthine oxidase from goat milk falls around the range of $23^{\circ} \mathrm{C}$ reported by Fried et al, ${ }^{11}$

It has earlier been shown that xanthine oxidase has found application in fish industries where it is used to detect fish freshness ${ }^{8}$ and in medical diagnostic laboratories ${ }^{9}$. The present observation therefore suggests further that xanthine oxidase from cow milk with optimum temperature of $10^{\circ} \mathrm{c}$ may be more applicable to the fish industry which involves cold processes while xanthine oxidase from goat milk would be more useful in medical diagnostic laboratories which involves processes of milder temperatures.

The $\mathrm{pH}$ profile of xanthine oxidase from cow and goat milk is shown in Fig.2. The optimum $\mathrm{pH}$ observed for xanthine oxidase from cow is 7.5 while that observed for goat milk sample ranges from $7.2-7.4$. The optimum $\mathrm{pH}$ for xanthine oxidase from cow milk observed in the present study is in agreement with the values of 7.5 reported for xanthine oxidase for cow milk by Giller et al ${ }^{12}$

The difference in optimum $\mathrm{pH}$ of xanthine oxidase from cow milk compared with that from goat milk as shown in the present study further reveals that xanthine oxidase from different sources differ in their basic characteristics and further suggests that xanthine oxidase from different sources may be suitable for different processes.

The substrate effect and line weaverburk plot of xanthine oxidase from cow and goat milk are shown in Fig. 3-6. The substrate activity profile observed in the present study follows the popular Michaelis - menten's formant. Xanthine oxidase from Cow milk shows a $\mathrm{K}_{\mathrm{m}}$ value of $0.86 \times 10^{-2} \mathrm{M}$ and $\mathrm{V}_{\text {max }}$ of $3.17 \mathrm{M} \mathrm{sec}^{-1}$, while the values observed for goat milk sample were $4.36 \times 10^{-2} \mathrm{M}$ and $2.00 \mathrm{M} \mathrm{sec}^{-1}$ for $\mathrm{K}_{\mathrm{m}}$ and $\mathrm{V}_{\max }$ respectively. The observed difference in kinetic parameter confirms that xanthine oxidase from cow milk differs in their basic characteristics from xanthine oxidase from goat milk. A high $\mathrm{K}_{\mathrm{m}}$ indicates a less stable Es complex whereas a high $\mathrm{V}_{\max }$ indicates a high turnover rate from Es complex to product $^{7}$. It is expected therefore that goat milk xanthine oxidase with higher $\mathrm{K}_{\mathrm{m}}$ would have a less stable
Es complex thereby giving a high turnover rate, but the observed $\mathrm{V}_{\max }$ of xanthine oxidase of goat milk is lower. This suggests that Es complex of goat milk xanthine oxidase dissociate fast but do not form products. It may therefore be that $\mathrm{K}_{2}$ of the Michaelis - menten's equation is prominent, thereby Es complex yields $\mathrm{E}+\mathrm{S}$.

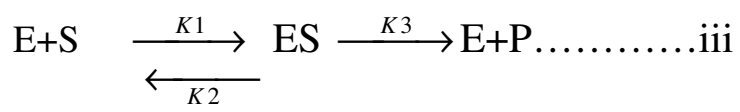

The observed difference in $\mathrm{K}_{\mathrm{m}}$ and $\mathrm{V}_{\max }$ has been attributed to the influence of changes in ${ }^{13}$.

The cow milk xanthine oxidase has a high turnover rate of $3.17 \mathrm{M} \mathrm{sec}^{-1}$. It therefore suggests that $\mathrm{K}_{3}$ is very prominent in the activity of xanthine oxidase from cow milk. The present observation indicates that the dissociation of Es is driven forward by $\mathrm{K}_{3}$ to yield product.

The present observation further confirms that xanthine oxidase from different sources are different in their basic characteristics. This also agrees with earlier reports that xanthine oxidase from different species are different ${ }^{1}$.

This study concludes that xanthine oxidase from different species are not only different in there basic characteristics but are also different in their catalytic properties. The difference in xanthine oxidase from different milk origins suggests their difference in evolutionary perfection and may be used to for speciation. The work has also shown that xanthine oxidase from cow milk may be better applied in the fish industry while that from goat milk may be better be applied in medical diagnosis.

\section{REFERENCES}

1. Massey, V, Brumby, P.E, Komai, H, (1969) Studies on Milk Xanthine Oxidase. J. Biol Chem. 244: 1682 -1691

2. Bray, R., Malmstran, B., and Vanngard, T; (1959) The Chemistry Of Xanthine Oxidase 5. Electronspin Resonnance of Xanthine oxidase solutions. Biochem. J. 73: 193.

3. Mccord J.M., (1985) Oxygen - deriven Free Radicals in Post ischemic Tissue injury N. Engl. J. Med. 312: 159 - 163 
4. Zweier J. L., Kuppusamy P., Luthy G. A., (1988) Measurement of Endothelial Cell Free Radical Generation ; Evidence for a central mechanism of free radical injury in postchemic Tisues. Proc. Natt. Accad. Sci; U.S.A 85: 4046 - 4050.

5.Izotov M.C., Scherbakov V.M; Spiridomova S.M; Devrchenskiny V.M; Benediktova S.A, (1991). Application Of Electron - Donor Properties Of Glucose Oxidase And Xanthine Oxidase For Reduction Of Microsomal NADCP) $\mathrm{H}$ - dependent Election - Transport Chains. Biotechnol. Appl. Biochem. 13 : $90-96$

6. Greed W.A; Bell, A; Urem J.R (1981) Intracellular Activity enzymes: In Antitumor Compounds of Natural Origin: Chemistry and Biochemistry Vol. 1 Ed. Adorjan Aszalos; CRC Press; Inc. Florida Pg 147

7. Bohinski, R. C.(1983) Mordern concept of Biochemistry. $4^{\text {th }}$ Edition, Allyn and Bacon, Inc., Newton Massachusetts. Pg . 130-135

8. Swaisgood N.E (1991) Immobilized Enzymes : In Food Enzymology. Elsevier N.Y.pg $182-195$

9. Pecht I; And Reiml D (1990) Bioprobes : Erv. Mon. Ass. 15: 1 - 12.

10. Beckman, J. Parks, D, Pearson, J., Marshall, P And Freeman, B (1989) A Sensitive Flourometric Assay On Measuring Xanthine Delydrogenase And Oxidase In Tissue, Free Radical Biol. Med. 6:607.

11. Fried R, Fried L.W; Babin D.R, (1973) Bilogic Rate Of Xanthine Oxidase and Tetrazolium Reductase inhibitor. Evr. J. Biochem. 33:439 - 445

12. Giller, S., Sperling, O., Brosh, S., Urca, I., And Davries, A, (1975 ) Xanthine Oxidase : In Butter Milk. Clinical Chem. Acta, 63:7.

13. Howard, H.W and Hevewala, N.B (1972) Continuous Production of Dextrose From Corn Starch. A Study of Reactor parameters Necessary for Commercial
Application. Biotech. and Bioeng. Sump. No. 3, $241-266$. 